\title{
Clipping Frequency Affects Canopy Volume and Biomass Production in Planeleaf Willow (Salix planifolia var. planifolia Prush)
}

\author{
Mark S. Thorne, ${ }^{1}$ Paul J. Meiman, ${ }^{2}$ Quentin D. Skinner, ${ }^{3}$ \\ Michael A. Smith, ${ }^{3}$ and Jerrold L. Dodd ${ }^{4}$ \\ Authors are ${ }^{1}$ State Range Extension Specialist, Human Nutrition, Food and Animal Sciences Department, University of Hawaii at \\ Manoa, Honolulu, HI 96822; ${ }^{2}$ Extension Range Specialist, Department of Renewable Resources, University of Wyoming, \\ Laramie, WY 82072; ${ }^{3}$ Professors, Department of Renewable Resources, University of Wyoming, Laramie, WY 82072; and \\ ${ }^{4}$ Chair/Professor, Agricultural Department, Cameron University, Lawton, OK 73505.
}

\begin{abstract}
Willows (Salix) are often a key component of riparian ecosystems and are often browsed by both wildlife and livestock. However, little is understood about how the frequency of browsing affects aboveground and belowground willow production. The objectives of this study were to determine how the frequency of simulated browsing events in a controlled environment affected 1) the aboveground, belowground, and total biomass production and 2) the canopy volume of planeleaf willow (Salix planifolia var. planifolia Prush) plants. The experiment was a completely randomized block design consisting of 2 groups of willow plants with different clipping histories. Within each group, plants were randomly assigned to 1 of 11 subgroups. Clipping events comprised of all combinations of early, middle, and late season periods were imposed on the treatment subgroups, while 1 subgroup served as the control. Canopy volume measurements were made before and after each clipping event. Canopy volume change was related to the harvested twig length $(\mathrm{cm})$ and weight $(\mathrm{g})$. Results suggested that frequency of clipping alone did not explain differences in aboveground and belowground willow production. Instead, willow production was influenced by an accumulation of specific combinations of seasonal clipping events and was dependent on the clipping history of the plants. Early season clipping, alone or in combination with other events, was more detrimental to willows with prior clipping histories than middle or late season clipping treatments. Willow with prior clipping histories treated in either the middle or late seasons, and the late/middle combination produced more than the controls. These results should be verified in willow communities subjected to natural environmental variations and browsing.
\end{abstract}

\section{Resumen}

Los "Willows" (Salix) a menudo son un componente clave de los ecosistemas ribereños y a menudo son ramoneados por la fauna silvestre y el ganado doméstico. Sin embargo, esta poco entendido como la frecuencia de ramoneo afecta la producción de biomasa aérea y subterránea de los "Willows". Los objetivos de este estudio fueron determinar como la frecuencia de eventos de ramoneo simulado en un ambiente controlado afecta 1) la producción de la biomasa aérea, subterránea y total y 2) el volumen de la copa de las plantas de "Planeleaf willow" (Salix planifolia var. planifolia Prush). El experimento se realizó bajo un diseño de bloques completos al azar consistiendo de dos grupos de plantas de "Willow" con diferentes historias de defoliación. Dentro de cada grupo, las plantas fueron asignadas aleatoriamente a 1 de 11 subgrupos. Eventos de corte comprendiendo todas las combinaciones de los periodos de inicios, mediados y fin de la estación fueron impuestos a los subgrupos de tratamientos, mientras que un subgrupo sirvió como control. Las mediciones de volumen de la copa fueron hechas antes y antes de cada evento de corte. El cambio del volumen de la copa estuvo relacionando con la longitud $(\mathrm{cm})$ y peso $(\mathrm{g})$ de las ramillas cosechadas. Los resultados sugieren que la frecuencia de corte sola no explica las diferencias en la producción de biomasa aérea y subterránea del "Willow". En cambio, la producción de "Willow" fue influenciada por una acumulación de combinaciones especificas de eventos estacionales de defoliación y fue dependiente de la historia de defoliación de las plantas. La defoliación a inicios de la estación, sola o en combinación con otros eventos, fue mas detrimental para el "Willows" con historias de defoliación previas a los tratamientos de mediados o fines de la estación. Los "Willows" con historias de defoliación previas tratados tanto a mediados a fines de la estación, y la combinación fines/mediados produjeron mas que las plantas del tratamiento control. Estos resultados deben ser verificados en comunidades de "Willow" sujetas a variaciones ambientales y ramoneo.

Key Words: riparian systems, streambank erosion, herbivory

Research was funded in part by the Wyoming Water Resources Center, the Hyatt Ranch, the Pitchfork Ranch, the WesMar Grazing Management Trust Fund, and the SRM Hyatt Trust. At the time of research, the senior author was research assistant, Department of Renewable Resources, University of Wyoming. Correspondence: Dr Mark S. Thorne, Kamuela Extension Office, 67-5189 Kamamalu Road, Kamuela, HI 96743. Email: thornem@hawaii.edu 


\section{INTRODUCTION}

While the aboveground biomass of riparian vegetation provides important resources for wildlife and livestock, root systems of riparian vegetation are widely accepted as important for streambank stability (Kauffman and Krueger 1984; Kleinfelder et al. 1992; Dunaway et al. 1994; Zonge et al. 1996). Increased rates of streambank erosion have been attributed to losses of riparian vegetation following groundwater extraction in California (Groeneveld and Griepentrog 1985), drought in the Sierra Nevada Mountains (Zonge et al. 1996), and livestock bank damage (Myers and Swanson 1992). While there are few studies that have illustrated that willow root systems may provide some level of streambank stability (Abernathy and Rutherford 2001; Simon and Collison 2002), these studies also demonstrated that hydrologic and mechanical processes were just as significant in determining streambank stability. Thus, it remains unclear how much willow roots contribute to the overall stability of riparian ecosystems where they occur.

The effect of herbivory on riparian areas has been well documented (Platts 1981; Roath and Krueger 1982; Kauffman and Krueger 1984; Green and Kauffman 1995). Other studies have documented the decline or disappearance of willow communities following extended periods of heavy browsing (Chadde and Kay 1991; Singer et al. 1994). While better management practices have been suggested, Green and Kauffman (1995) pointed out that "blanket recommendations" (uniform use levels and stubble height standards) ignore the complexity of riparian ecosystems. Instead, they suggested that grazing prescriptions be developed for each riparian area independently. Perhaps management could also be enhanced with a better understanding of the response of aboveground and belowground portions of riparian vegetation to herbivory, since willows are often a key component of riparian ecosystems that are browsed by both wildlife and livestock.

Investigations on the influence of herbivory on grassland vegetation indicate that root growth and resource allocation are important responses (Chapin and Slack 1979; Caldwell et al. 1981; Richards and Caldwell 1985; Briske and Richards 1995; Engel et al. 1998). While aboveground response of shrubs to herbivory, including willow, has been thoroughly described (Willard and McKell 1978; Wolff 1978; Wolfe et al. 1983; Kindschy 1985; Kindschy 1989; Singer et al. 1994); root responses, with one exception, have not. Meiman (1996) reported results of the effects of season and intensity of clipping events on aboveground and belowground production of planeleaf willow (Salix planifolia Prush). He found that clipping intensity $(0 \%, 30 \%$, and $60 \%$ of current years growth) and season of clipping (prebud, full leaf, and dormant) had little effect on aboveground biomass production in planeleaf willow. However, while the season and season by intensity interaction were not significant, root production decreased as intensity increased. While Meiman's (1996) study addressed several important questions, results did not explain the aboveground and belowground responses to the frequency of browsing events within a growing season. We initiated this study in 1995 to investigate the response of planeleaf willow to simulated browsing under controlled environmental conditions. The purpose of this study was to determine how the frequency of simulated browsing events in a controlled environment affects 1) the aboveground, belowground, and total biomass production and 2) the canopy volume of planeleaf willow plants.

\section{MATERIALS AND METHODS}

\section{Study Site}

This study was conducted in a common garden at the University of Wyoming's greenhouse facility in Laramie. Plants used in this study were grown from stem cuttings of planeleaf willow collected from a montane site in the Bighorn National Forest of northern Wyoming. Cuttings were taken from a meadow (Willow Swamp) at $2675 \mathrm{~m}$ in elevation on 25 May 1994. The meadow was dominated by bog birch (Betula glandulosa Michx.) and planeleaf willow (Meiman 1996).

Basal stems with diameters ranging from 13-20 mm were cut to $45-\mathrm{cm}$ lengths. Stem material was kept cool, moist, and protected from light during transport to the greenhouse facility. On 31 May 1994 cuttings were treated with a fungicide (Captan) and placed in a misting bench for root establishment. The basal $15 \mathrm{~cm}$ of the cuttings was covered with a mixture of perlite and vermiculite rooting media. After 10 days in the misting bench, root and leaf growth was apparent. Plants were potted on 14 June 1994, when most stems had emerging leaves and several roots about $2-\mathrm{cm}$ long. The cuttings were potted in tall, 1-gallon tree pots with mortar sand and treated every 3-4 months with a slow release Nitrogen/Phosphorous/Potassium (NPK) fertilizer. Micronutrients were applied as needed based on soil tests and leaf symptoms. The plants were maintained in the greenhouse until November 1994. They were then moved to an unheated metal building to initiate dormancy.

On 25 March 1995 the willows were repotted in 4-gallon tree pots and transferred into the Environmental Simulation Facility (ESF) for the purpose of conducting a twig dieback study (Meiman 1996). The ESF is located in the Department of Renewable Resources at the University of Wyoming and is a large scale chamber where light intensity, day length, temperature, and relative humidity can be controlled (Skinner et al. 1989). During the twig dieback study, the chamber was programmed to simulate average diurnal temperatures, relative humidity, and day length patterns for the months of June, July, and August at Willow Swamp. Plants in the ESF were irrigated with an automated microtube watering system. One-half of the plants in this study underwent clipping treatments to determine the effects of clipping on the length of dieback in willow branches. The remaining willow plants served as controls for the study and were not clipped.

The twig dieback study was terminated on 21 June 1995 (Meiman 1996). At this time, the willows were repotted in cylinders $(15 \mathrm{~cm}$ diameter $\times 100 \mathrm{~cm}$ height $)$ similar to those used by Engel (1993) and following procedures detailed by Meiman (1996). The bottom of the cylinders were sealed with a root barrier fabric allowing water and air to pass through but containing the roots. Cylinders were lowered into holes $(20 \mathrm{~cm}$ diameter $\times 1 \mathrm{~m}$ depth) centered within a $2-\times 1$-m plot, so that the soil surface inside the cylinder was approximately even with the soil surface outside. The top edge of the cylinders extended about $10 \mathrm{~cm}$ above the soil surface. Willow plants were watered with an automated microtube irrigation system and 


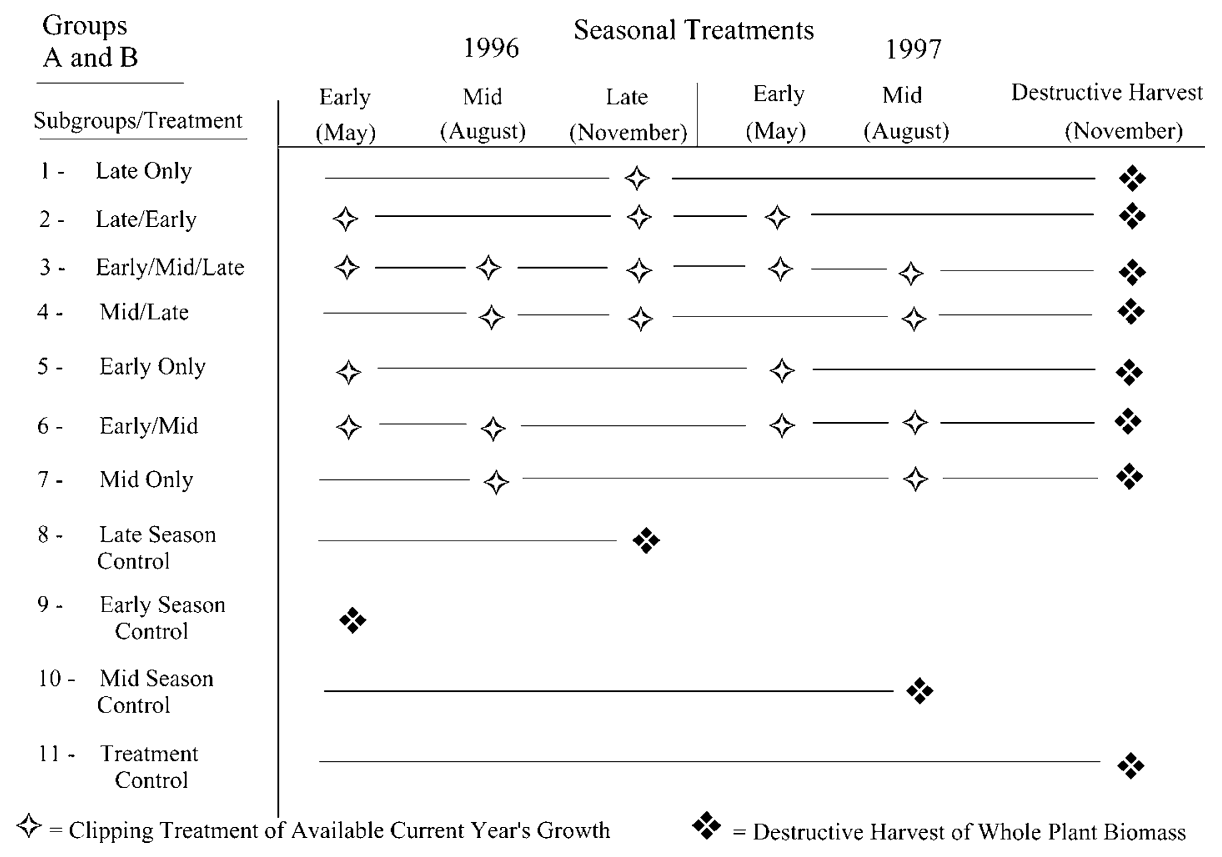

Figure 1. Frequency of clipping study design showing the sequence of clipping events for both treatment groups A (previous clipping history) and B (no clipping history) and the destructive harvest schedule of control (8-11) and treatment subgroups (1-7). Available current year's growth was clipped at rates of $50 \%$ for single frequency treatment groups, $25 \%$ for 2 frequency treatment groups, and $16.6 \%$ for the 3 frequency treatment.

treated every 3-4 months with a slow release NPK fertilizer. Micronutrients were applied as needed based on soil tests and leaf symptoms. No clipping treatments were imposed during the 1995 growing season to allow the willows time to adjust to the garden environment.

\section{Experimental Design}

The experiment was a completely randomized block design. Blocks consisted of 2 groups (A and B) of willow plants separated based on their treatment history in the ESF (Fig. 1). Group A consisted of willow plants with prior clipping treatments and group B was comprised of willows with no clipping history. Separation (blocking) of the 2 groups allowed for isolation of possible residual effects from the clipping treatments used in the twig dieback study (Meiman 1996).

Within each group, plants were randomly assigned to 1 of 11 subgroups so that each contained 7 plants (Fig. 1). Each plant was considered an experimental unit. Treatment groups 1 through 7 were clipped either 1, 2, or 3 times per year in all possible combinations of early, middle, and late season periods, to correspond to 3 physiological stages (prebud, full leaf, and dormant) in willow development over 1 growing season. To achieve a constant intensity of clipping treatments at $50 \%$ removal of the annual growth, the periodic rate of clipping was varied at $50 \%, 25 \%$, and $16.6 \%$ of the current annual growth (cm) for clipping frequencies of 1, 2, and 3, respectively. Current year's twig lengths were measured at each seasonal clipping event to determine the amount to remove for each frequency treatment. For the single clipping treatments (early only, middle only, and late only), a rate of $50 \%$ of the current year's twig growth was achieved by removing half of the available twig material in the respective season. The amount removed during any 1 clipping event for either the 2 or 3 frequency treatments was determined by summing previously removed twig material to the currently available twig material and removing the necessary length so that $50 \%$ of the annual growth was removed by the end of the growing season. Entire twigs and any associated leaves were removed from each plant in all frequency treatments using clippers sterilized in a $10 \%$ Clorox solution. Plants were clipped from May (early or prebud) 1996 through August (middle or full leaf) 1997. For the early season treatments (May 1996 and May 1997) the previous year's twigs were clipped since the current year's growth was not yet present.

Subgroups 8, 9, and 10 were untreated and destructively harvested at different times over the course of the experiment (November 1996, May 1996, and August 1997, respectively) to estimate the growth patterns of potted willow plants. Subgroup 11 remained untreated and served as the experimental control. Treatments 1 through 7 and control group 11 were destructively harvested on 17 November 1997 (Fig. 1).

Immediately before and after each seasonal treatment, canopy volume was measured on all plants. Canopy volume readings began during the midseason treatment on 8 August 1996, and continued through the destructive harvest 17 November 1997. With the ellipsoid model [willow canopy volume $=(2 / 3) \pi H(A / 2 \times B / 2)$, where $H$ is plant height, and $A$ and $B$ are diameter measurements] described by Thorne et al. (2002), canopy volume was derived from the height and 2 diameter measurements taken at $50 \%$ of the height for each plant.

All clipped material removed during treatments, the aboveground biomass of subgroups $8,9,10$, and 11 , and the residual aboveground biomass of treatment groups 1 through 7 were oven dried at $60^{\circ} \mathrm{C}$ and weighed. Root cores for all 11 subgroups were washed (see Lauenroth and Whitman 1971), 
Table 1. Mean ( \pm SE) planeleaf willow belowground and aboveground; total biomass $(\mathrm{g})$ for clipping frequencies of 1,2 , and 3 ; and the treatment control (0 clipping events).

\begin{tabular}{ccccc}
\hline $\begin{array}{c}\text { Frequency of } \\
\text { Clipping }\end{array}$ & Biomass $(\mathrm{g})$ & \\
\cline { 2 - 4 } & Belowground & Aboveground & Total & $\mathrm{N}$ \\
\hline 1 & $216 \pm 19.9$ & $192 \pm 13.9$ & $407 \pm 32.1$ & $42^{1}$ \\
2 & $170 \pm 19.2$ & $172 \pm 15.3$ & $343 \pm 31.6$ & $42^{2}$ \\
0 & $163 \pm 35.7$ & $168 \pm 28.9$ & $332 \pm 60.1$ & $14^{3}$ \\
3 & $149 \pm 25.8$ & $137 \pm 18.3$ & $286 \pm 42.7$ & $14^{4}$ \\
\hline
\end{tabular}

${ }^{1}$ The single clipping frequency is comprised of the early-only $(n=7)$, middle-only $(n=7)$, and late-only $(n=7)$ treatments from groups A (previous clipping history) and $\mathrm{B}$ (no clipping history)

${ }^{2}$ The clipping frequency of 2 events per year were the early/late $(n=7)$, middle/late $(n=7)$, and early/middle $(n=7)$ treatments from groups A (previous clipping history) and B (no clipping history).

${ }^{3}$ Clipping treatments were not imposed on the treatment controls $(n=7)$ of groups $\mathrm{A}$ (previous clipping history) and B (no clipping history).

${ }^{4}$ For groups $A$ (previous clipping history) and $B$ (no clipping history), the 3 treatment frequency $(n=7)$ was comprised of clipping events in the late, early, and middle seasons.

dried at $60^{\circ} \mathrm{C}$, and weighed. The dry weights of the clipped and residual aboveground biomass were combined for each treatment group to estimate total aboveground biomass.

\section{Statistical Analyses}

Response variables were residual aboveground (plant material remaining at destructive harvest), total aboveground (residual aboveground + clipped twig material), belowground, and total biomass production (total aboveground + belowground), and final canopy volume (plant volume at destructive harvest) for all treatments and the control (11). Since each treatment was a combination of seasonal periods (early, middle, late) chosen to achieve the desired number of clipping events (frequencies), season and frequency of clipping were not independent factors and their influence could not be separated. Therefore, our analysis of the production data entailed a 2-step process. First, a 2-way analysis of variance (ANOVA) procedure was used to determine the effect of group (A and B), treatment (1-7 and 11 ), and group $\times$ treatment interaction on the response variables (Dowdy and Wearden 1991). Second, treatment groups were combined by frequency of clipping and analyzed using a general linear model, 2-factor ANOVA procedure (Dowdy and Wearden 1991). The model factors included group (A and B), frequency $(1,2$, and 3 clippings), and a group $\times$ frequency interaction term to test for effects on the response variables. The first analysis provided information on the effects of a combination of seasonal clipping events for which season and frequency of clipping were integral parts. Combining treatments by frequency of clipping in the second analysis "subtracted out" the effects of season so that variance estimates were based only on the number of clipping events per year.

Regression analysis procedures were used to examine the relationship between treatment effects and canopy volume (Neter et al. 1996). The first regression analysis was conducted to confirm the relationship between final canopy volume (CV, explanatory variable) and residual aboveground biomass (dependent variable). Regression analyses were performed using change in canopy volume (CV after treatment - CV before treatment) as the explanatory variable and seasonally harvested twig lengths and weights as dependent variables. A repeatedmeasures ANOVA procedure (Vonesh and Chinchilli 1997) was used to detect dependencies of change in canopy volume, harvested twig lengths, and harvested twig weights (response variables) on treatment factors (group, season, group $\times$ season interaction, and frequency nested in season).

Standard statistical tests were conducted to assure that all assumptions concerning ANOVA, linear regression, and repeated-measures ANOVA procedures were met (Dowdy and

Table 2. Mean $( \pm \mathrm{SE})$ total, aboveground, and belowground biomass production $(\mathrm{g})$ of planeleaf willow plants for groups $A$ (previous clipping history) and B (no clipping history), each with 7 clipping frequency treatments (1-7) removing $50 \%$ of the annual growth, comprised of all possible combinations of 3 seasonal periods and an untreated control (11). Treatments are organized from lowest to highest average total biomass.

\begin{tabular}{|c|c|c|c|c|c|c|c|c|c|}
\hline \multirow[b]{3}{*}{ Response } & \multicolumn{8}{|c|}{ Treatment } & \multirow{3}{*}{$\begin{array}{l}\text { Group } \\
\text { Means }\end{array}$} \\
\hline & (2) & (3) & (11) & (6) & (5) & (1) & (4) & (7) & \\
\hline & Early/late & Early/middle/late & Treatment control & Early/middle & Early only & Late only & Middle/late & Middle only & \\
\hline \multicolumn{10}{|c|}{ Total Biomass $^{1}$} \\
\hline Group A & $221.1(81.3)$ & $250.1(65.5)$ & $309.2(102.0)$ & $253.5(69.2)$ & $227.2(26.9)$ & $424.1(93.3)$ & $343.4(81.2)$ & $504.2(83.5)$ & $316.6^{2}(28.9)$ \\
\hline Group B & $282.7(54.1)$ & $321.8(56.3)$ & $354.3(71.2)$ & 436.1 (77.4) & 506.7 (89.6) & $320.8(64.7)$ & $519.3(54.4)$ & $460.3(56.7)$ & $400.3(24.9)$ \\
\hline Average & $251.9^{\mathrm{a}}(47.7)$ & $285.9^{\mathrm{ab}}(46.7)$ & $331.8^{\mathrm{abc}}(60.1)$ & $344.8^{\mathrm{abc}}(55.9)$ & $366.9^{\text {abcd }}(59.4)$ & $372.4^{\text {bcd }}(56.4)$ & $431.4^{\mathrm{cd}}(52.9)$ & $482.3^{d}(48.9)$ & - \\
\hline \multicolumn{10}{|c|}{ Aboveground ${ }^{1}$} \\
\hline Group A & $110.9(36.2)$ & $119.0(28.8)$ & $149.4(47.9)$ & 131.6 (39.6) & $114.4(17.3)$ & $168.8(41.0)$ & $179.3(50.2)$ & $254.9(30.8)$ & $153.6^{2}(13.9)$ \\
\hline Group B & $162.5(34.9)$ & $154.6(22.6)$ & $187.2(34.5)$ & $203.5(18.8)$ & $212.1(37.7)$ & $171.9(31.2)$ & $246.2(25.1)$ & $226.8(23.7)$ & 195.6 \\
\hline Average & $136.7^{\mathrm{a}}(6.7)$ & $136.8^{\mathrm{a}}(4.9)$ & $168.3^{\mathrm{ab}}(7.7)$ & $167.6^{\mathrm{ab}}(6.2)$ & $163.3^{\mathrm{ab}}(6.4)$ & $170.4^{\mathrm{ab}}(6.6)$ & $212.8^{\mathrm{bc}}(7.6)$ & $240.9^{c}(5.1)$ & - \\
\hline \multicolumn{10}{|c|}{ Belowground $^{3}$} \\
\hline Group A & $110.1^{\mathrm{a}}(48.0)$ & $131.0^{\mathrm{ab}}(36.9)$ & $159.8^{\mathrm{abcd}}(67.8)$ & $121.9^{\mathrm{a}}(35.4)$ & $112.8^{\mathrm{a}}(20.77)$ & $255.3^{\text {de }}(55.7)$ & $164.1^{\mathrm{abcd}}(35.5)$ & $249.3^{\text {cde }}(55.2)$ & $163.0^{2}(16.8)$ \\
\hline Group B & $120.2^{\mathrm{a}}(24.3)$ & $167.3^{\text {abcd }}(37.6)$ & $167.1^{\mathrm{abcd}}(41.1)$ & $232.5^{\text {bcde }}(64.8)$ & $294.5^{\mathrm{e}}(55.3)$ & $148.9^{\mathrm{abc}}(36.2)$ & $273.1^{\mathrm{e}}(40.9)$ & $233.5^{\text {bcde }}(36.4)$ & $204.6(16.4)$ \\
\hline
\end{tabular}


Table 3. Shoot:root ratios ${ }^{1}$ of planeleaf willow plants for groups A (previous clipping history) and B (no clipping history), each with 7 clipping frequency treatments (1-7) removing 50\% of the annual growth, comprised of all possible combinations of 3 seasonal periods and an untreated control (11). Treatments are organized from lowest to highest average total biomass.

\begin{tabular}{lcccccccc}
\hline & \multicolumn{7}{c}{ Treatment } \\
\cline { 2 - 9 } Group & $\begin{array}{l}(2) \\
\text { Early/late }\end{array}$ & Early/middle/late & Treatment control & $\begin{array}{c}(6) \\
\text { Early/middle }\end{array}$ & $\begin{array}{c}(5) \\
\text { Early only }\end{array}$ & $\begin{array}{c}(1) \\
\text { Late only }\end{array}$ & $\begin{array}{c}(4) \\
\text { Middle/late }\end{array}$ & Middle only \\
\hline A & 1.1 & 0.91 & 0.93 & 1.1 & 1.0 & 0.66 & 1.1 & 1.0 \\
B & 1.4 & 0.92 & 1.1 & 0.88 & 0.72 & 1.2 & 0.9 & 0.97 \\
\hline
\end{tabular}

${ }^{1}$ shoot:root ratio, aboveground biomass divided by the belowground biomass.

Wearden 1991; Neter et al. 1996; Vonesh and Chinchilli 1997). Fisher's least significant difference (LSD) was used to separate means when ANOVA procedures indicated significant differences (Dowdy and Wearden 1991). Because of the limited sample size all mean separation tests were conducted at an overall $\alpha$ of 0.10 and the appropriate degrees of freedom for a particular ANOVA.

\section{RESULTS AND DISCUSSION}

\section{Clipping Frequency and Willow Biomass}

Results showed that frequency of clipping alone $(1,2$, or 3 clipping events regardless of seasonal combination) had little effect on willow biomass $(P>0.10$; Table 1$)$. Rather, it was specific combinations of different seasonal clipping events that produced the largest variations in willow production among treatments. While the response of total biomass (total aboveground + belowground biomass) highlights the general trends in the treatment effects (Table 2), specific trends in willow production are more relevant in the context of the differences between groups $\mathrm{A}$ and $\mathrm{B}$, and the ratio of aboveground to belowground biomass (shoot:root ratio; Table 3). Group means were significantly larger in group B (no previous clipping treatment) than in group A (clipped in a previous experiment) for total aboveground $(P=0.015)$, belowground $(P=0.065)$, and total biomass $(P=0.024)$. On average, group B produced $21 \%$ more than group A in total aboveground, belowground, and total biomass (Table 2). The group $\times$ treatment interaction was significant for belowground biomass $(P=0.06)$ but not for any other response variable $(P>0.10)$. Treatment means varied significantly for total aboveground biomass $(P=0.038)$ and total biomass $(P=0.053)$. We attributed differences between groups $\mathrm{A}$ and $\mathrm{B}$ to residual effects from the twig dieback study in the ESF (Meiman 1996). Even though plants in both groups were "rested" for a growing season (1995) in an attempt to normalize the 2 groups, differences were apparent. Generally, plants in group $\mathrm{B}$ were larger and produced more aboveground and belowground biomass than plants in group A. Further, belowground biomass of treatments in group B responded differently than in group A.

Having been previously clipped, plants in group A may have preferentially allocated plant resources to shoot elongation at the expense of root growth, especially in the early season treatments. While this response has not been reported previously for other riparian shrubs, this response has been observed in perennial grasses (Caldwell et al. 1981; Richards and Caldwell 1985; Bilbrough and Richards 1993; Briske and Richards 1995). In contrast, group B plants may have initially maintained resource allocations proportional to the maintenance of roots over shoots. For example, the group $\times$ treatment interaction in belowground biomass was most evident in the early-only, early/middle and middle/late treatments (Table 2). The early-only, early/middle, and middle/late treatments in group A produced less root mass than in group B, but maintained shoot:root ratios near 1 (Table 3). Alternatively, group B shoot:root ratios for the early-only, early/middle, and middle/late treatments were less than 1 , indicating a greater allocation of plant resources to maintenance of root growth over shoot elongation (Table 3).

Briske and Richards (1995) noted that perennial grass plants respond to chronic and single-event defoliations differently. Plants under chronic defoliation alter resource allocation patterns and reduce relative growth rates among aboveground and belowground portions. Alternatively, single-event defoliations impose a transient period of modified physiological function before recovery of steady-state plant function (Briske and Richards 1995). Group A plants in the early-only, early/ middle, and middle/late treatments appear to have exhibited altered resource allocation patterns relative to the controls, which maintained shoot:root ratios at 0.93 and 1.1 for groups A and B, respectively (Table 3). Specifically, consider that following clipping treatments, plant shoot:root ratios would become unbalanced relative to the controls, with more belowground than aboveground biomass. For group A to maintain shoot:root ratios in the early-only, early/middle, and middle/ late treatments near 1 and similar to the controls, shoot growth had to be favored over root growth. Thus, growth resources in group A were likely allocated, preferentially, to shoot elongation over root growth.

Group B plants in the early-only, early/middle, and middle/ late treatments appear to have responded as if the clipping treatments were single events. Resource allocation was not altered to favor shoots over roots, and continued root growth resulted in a disproportionate shoot:root ratio relative to the controls (Table 3). Recovery time between clipping events may have prolonged this manner of response in group B. Kindschy (1989) indicated that red willow (Salix lasiandra Benth.) experienced a 30-day "shock period" following top removal in which no regrowth occurred. The shortest time intervals between any 2 clipping events in our study were 79 and 92 days between the early and middle season clipping dates for 
Table 4. Mean ( $\pm \mathrm{SE})$ final canopy volume $\left(\mathrm{cm}^{3}\right)$ and residual aboveground biomass $(\mathrm{g})$ at the time of destructive harvest for planeleaf willow plants of groups A (previous clipping history) and B (no clipping history), each with 7 clipping frequency treatments (1-7) removing $50 \%$ of annual growth, comprised of all possible combinations of 3 seasonal periods and an untreated control (11). Treatments are organized from lowest to highest average final canopy volume.

\begin{tabular}{|c|c|c|c|c|c|c|c|c|c|}
\hline \multirow[b]{2}{*}{ Response } & \multicolumn{8}{|c|}{ Treatment } & \multirow[b]{2}{*}{$\begin{array}{l}\text { Group } \\
\text { Means }\end{array}$} \\
\hline & $\begin{array}{l}\text { (7) Middle } \\
\text { only }\end{array}$ & $\begin{array}{l}\text { (3) Early/ } \\
\text { middle/late }\end{array}$ & $\begin{array}{l}\text { (6) Early/ } \\
\text { middle }\end{array}$ & $\begin{array}{l}\text { (2) Early/ } \\
\text { late }\end{array}$ & $\begin{array}{l}\text { (5) Early } \\
\text { only }\end{array}$ & $\begin{array}{l}\text { (4) Middle/ } \\
\text { late }\end{array}$ & $\begin{array}{l}\text { (11) Treatment } \\
\text { control }\end{array}$ & $\begin{array}{c}\text { (1) } \\
\text { Late only }\end{array}$ & \\
\hline \multicolumn{10}{|l|}{ Final Canopy Vol. } \\
\hline Group A & $\begin{array}{c}81765 \\
(15331)\end{array}$ & $\begin{array}{c}72457 \\
(29671)\end{array}$ & $\begin{array}{c}82818 \\
(41384)\end{array}$ & $\begin{array}{c}91745 \\
(50778)\end{array}$ & $\begin{array}{c}59046 \\
(17673)\end{array}$ & $\begin{array}{l}176653 \\
(62481)\end{array}$ & $\begin{array}{l}163879 \\
(76496)\end{array}$ & $\begin{array}{l}239326 \\
(74000)\end{array}$ & $\begin{array}{l}120961^{1} \\
(18750)\end{array}$ \\
\hline Group B & $\begin{array}{l}105053 \\
(16282)\end{array}$ & $\begin{array}{l}117372 \\
(30676)\end{array}$ & $\begin{array}{l}116040 \\
(21281)\end{array}$ & $\begin{array}{l}107877 \\
(36829)\end{array}$ & $\begin{array}{l}219371 \\
(75379)\end{array}$ & $\begin{array}{l}119555 \\
(15905)\end{array}$ & $\begin{array}{l}232701 \\
(50819)\end{array}$ & $\begin{array}{l}163321 \\
(44961)\end{array}$ & $\begin{array}{l}134311 \\
(12043)\end{array}$ \\
\hline Average & $\begin{array}{l}93409^{a} \\
(11218)\end{array}$ & $\begin{array}{l}94914^{a} \\
(21427)\end{array}$ & $\begin{array}{l}99429^{a} \\
(22825)\end{array}$ & $\begin{array}{l}99811^{\mathrm{a}} \\
(30217)\end{array}$ & $\begin{array}{l}139209^{a b} \\
(43332)\end{array}$ & $\begin{array}{l}148104^{a b} \\
(31968)\end{array}$ & $\begin{array}{l}198290^{b} \\
(45138)\end{array}$ & $\begin{array}{l}201323^{b} \\
(42910)\end{array}$ & - \\
\hline \multicolumn{10}{|c|}{ Residual Aboveground } \\
\hline Group A & $163.7(19.0)$ & $98.3(23.4)$ & $102.3(29.8)$ & $101.3(32.1)$ & $106.6(17.1)$ & $144.8(41.9)$ & $149.4(47.9)$ & $159.0(38.4)$ & $128.2^{2}(11.4)$ \\
\hline Group B & $139.8(14.9)$ & $129.7(19.0)$ & $152.5(12.2)$ & $149.2(32.3)$ & $194.5(34.6)$ & $189.5(22.5)$ & $187.2(34.5)$ & $159.3(28.9)$ & $162.7(9.2)$ \\
\hline Average & 151.8 (3.2) & $113.9(4.1)$ & $127.4(4.5)$ & $125.2(6.1)$ & $150.6(5.9)$ & $167.2(6.3)$ & $168.3(7.7)$ & $159.1(6.2)$ & - \\
\hline
\end{tabular}

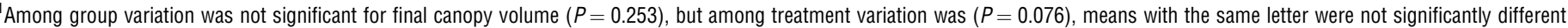
$\left(\mathrm{LSD}=77088.5 \mathrm{~cm}^{3}\right)$.

${ }^{2}$ Among group variation for residual biomass was significant $(P=0.022)$, but the among treatment variation was not $(P=0.465)$.

1996 and 1997, respectively. Thus, for group B plants, recovery time may have been sufficient enough that each event, in effect, was singular.

Plants in group B might have begun to respond similarly to group A, given enough successive growing seasons with similar clipping regimes. In fact, the rate at which plants begin to respond to chronic herbivory may be proportional to the frequency of herbivory within a growing season. Consider that in the group B early-only, early/middle, middle/late, and early/middle/late treatments the shoot:root ratio approaches 1 , and as additional clipping events were imposed, group B shoot: root ratio becomes more similar to the controls (Table 3). Additionally, the shoot:root ratios in the early/middle/late treatments of groups A and B are nearly identical, suggesting that the more frequent the clipping events, the more group $\mathrm{B}$ responded like group A (Table 3).

Still other factors may have contributed to the interaction in the late-only treatment between groups A and B (Table 2). Late season clipping could not have an effect on plant response until the spring when the plants broke dormancy. Aboveground production in the late-only treatment for groups A and B were similar, but belowground biomass was markedly greater in A than in B (Table 2). In this case the group A late-only treatment responded as if the clipping event was singular rather than part of a continuous sequence of events by allocating resources to producing more roots than shoot growth. On the other hand, group $\mathrm{B}$ increased aboveground production at the expense of root growth and maintenance. It is not readily apparent why this reversal existed in responses between the 2 groups, but the amount and type of twig material left after the late season clipping event may have influenced the different growth potentials when the plants broke dormancy.

In many willow species, short shoot and bud development are stimulated by and are readily converted (functionally) to long shoots when the apical meristem is removed (Dahl 1995).
A higher ratio of short shoots to long shoots increases the photosynthetic area of a plant (Dahl 1995). Group A plants had an increased number of short shoots and, by extension, greater photosynthetic area relative to plants in group B because of the prior clipping treatments imposed by Meiman (1996) during the twig dieback study. Although clipping treatments in our study removed equal portions of available current annual twig length (i.e., 50\%) from plants in both groups, the treatments may not have removed equal portions of the available photosynthetic area. Group A plants in the late-only treatment may have retained more photosynthetic area and, thus, had a greater photosynthetic capacity when dormancy broke than group B plants in the same treatment. Consequently, when plants in both groups broke dormancy following late season clippings, group A plants may not have allocated as much plant resources to replace lost photosynthetic area as group B plants. Instead, group A plants could have allocated photosynthates to root growth sooner than group B plants, while group B plants may have had to delay allocation of resources for root growth in order to restore photosynthetic capacity.

Middle-only treatment plants in groups $\mathrm{A}$ and $\mathrm{B}$ also maintained shoot:root ratios near 1 and similar to the controls despite removal of $50 \%$ of the current annual growth for 2 growing seasons (Table 3). Planeleaf willow production, both belowground and aboveground, seems to have been stimulated by a single middle season clipping event relative to the control (Table 2). In fact, plants in the middle season treatments on average produced $31 \%$ more total biomass than the control plants; possibly exhibiting an overcompensatory growth response. Apparently, aboveground growth before clipping in the middle-only treatment was sufficient to not only replace lost photosynthetic area but to maintain allocation to root production as well.

The compensatory response exhibited by the middle-only treatment plants likely occurred in the second growing season. In 
fact, while group A and B plants in the middle-only treatment grew an average of $12.2 \mathrm{~cm} / \mathrm{d}$ (total annual twig length $=967 \mathrm{~cm}$ in 79 days) in 1996, the growth rate doubled to $24.2 \mathrm{~cm} / \mathrm{d}$ (total annual twig length $=2225 \mathrm{~cm}$ in 92 days) in 1997. Since the plants were under the same watering and nutrient regime both years, the increased growth rate observed in the second growing season was probably not environmentally induced. Rather, evidence reported in the literature would suggest that this response was stimulated by the previous year's clipping. For example, Kindschy (1985) reported that red willow growth increased exponentially with an increase in the percent of shoots removed the previous autumn. Additionally, Kindschy (1989) noted that [individual] shoot elongation in cut (top removal) red willow plants was higher, averaging $3.3 \mathrm{~cm} / \mathrm{d}$, than uncut willows, which averaged $0.38 \mathrm{~cm} / \mathrm{d}$ in the first growing season following cutting. Similar responses were found in scouler willow (Salix scouleriana Barrett ex Hook.) by Wolff (1978), Salix arbusculoides Andderss. (DeGrosbois et al. 1991), and other shrub species including little rabbitbrush (Chrysothamnus viscidiflorus Hook.) and snowberry (Symphoricarpos vaccinioides Rydb.) by Willard and McKell (1978).

\section{Willow Canopy Volume}

Final canopy volume did not vary $(P>0.10)$ between groups, but residual aboveground biomass was significantly greater $(P=0.022)$ in group B than in group A (Table 4$)$. While the group $\times$ treatment interaction was not significant $(P>0.10)$ for either response, the treatment means varied significantly for final canopy volume $(P=0.076)$ but not for residual aboveground biomass $(P>0.10)$. Average final canopy volumes in the late-only treatment and treatment control were significantly larger $\left(\mathrm{LSD}=77088.5 \mathrm{~cm}^{3}\right)$ than those for all treatments except the early-only and middle/late treatments (Table 4).

Since groups A and B were significantly different with respect to final canopy volume, and because of the different histories in the ESF, the regression analyses were conducted for each group separately and then combined. In all 3 analyses, residual aboveground biomass (dependent variable) had a significantly $(P<0.01)$ positive linear relationship to final canopy volume (Fig. 2). In group A, more of the variability in the residual aboveground weight was explained by the final canopy volume than in group B (Fig. 2). The difference in the relationships between groups A and B is explained by differences in canopy structure and is also reflective of their different clipping histories in the ESF. Since clipping, browsing, and pruning stimulate short shoot development (Dahl 1995), it stands to reason that these events would also change the canopy structure of the plants.

Plants responding to a chronic herbivory regime would tend to be small and dense with short shoots occupying more intercanopy space compared with plants of the same age with no previous history of foliage removal and/or responding to single-event defoliations. Instead, plants in this latter category would display large, diffuse canopies defined by long shoots and a lack of short shoots occupying intercanopy space. Consequently, since canopy volume is an estimate of the actual space occupied by a shrub, we suggest a dense canopy should provide a better estimate of plant volume than a diffuse canopy. In addition, a small, dense canopy could have the same amount

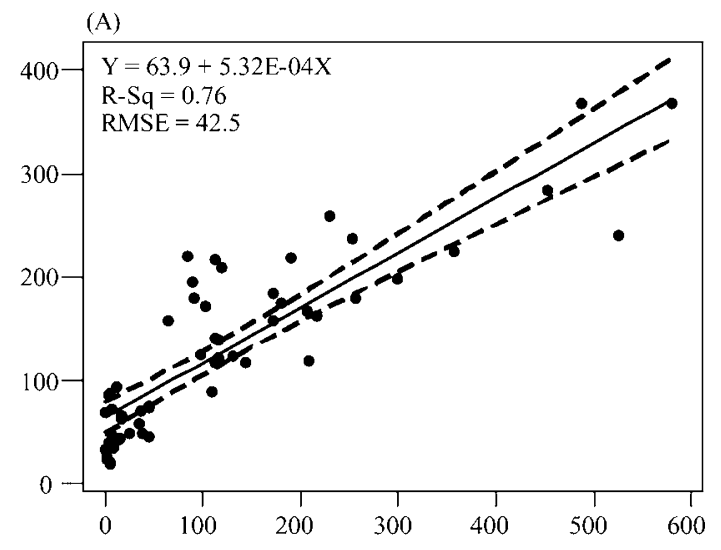

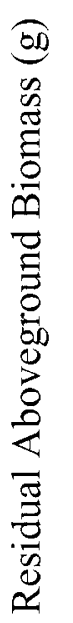
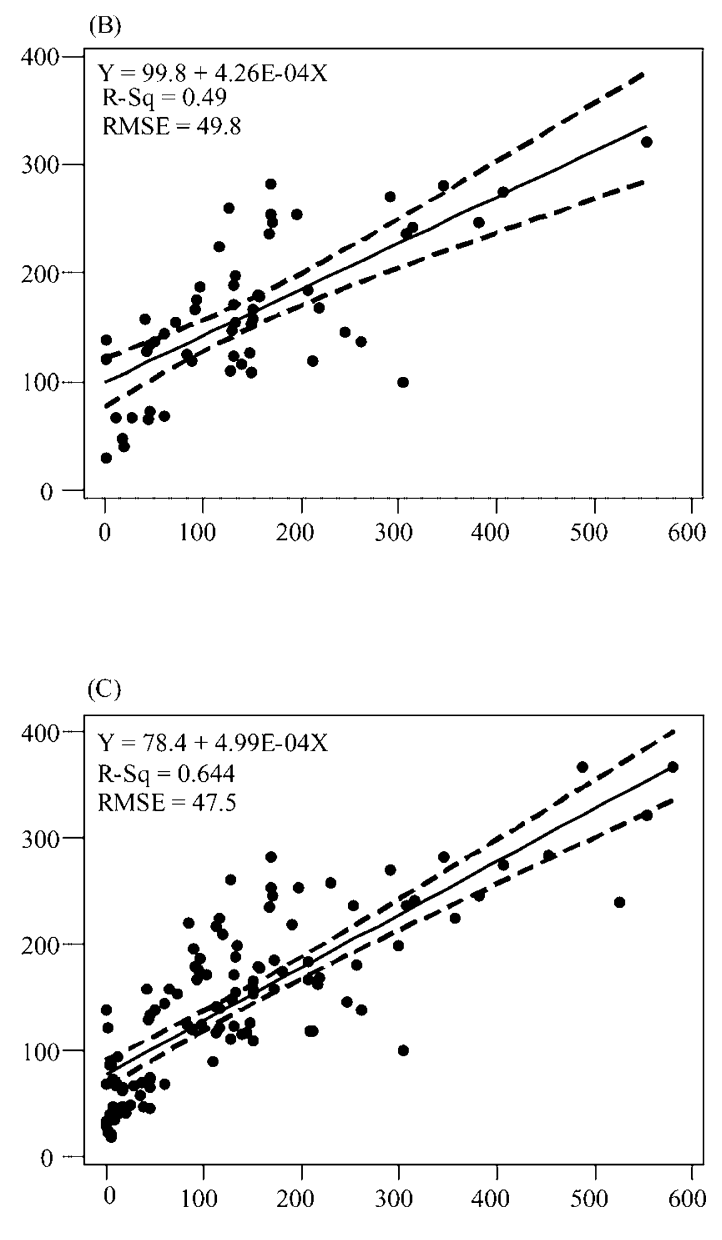

Final Canopy Volume $\left(\mathrm{cm}^{3} \times 10^{3}\right)$

Figure 2. Simple linear regression functions (solid line) with $95 \%$ confidence intervals (dashed lines), between final canopy volume $\left(\mathrm{cm}^{3}\right)$ and residual aboveground biomass ( $\mathrm{g}$ ) for $\mathbf{A}$, groups $\mathrm{A}$ (previous clipping history), B, group B (no clipping history), and C, groups A and B combined. RMSE, square root of mean square error (standard deviation of regression function). 

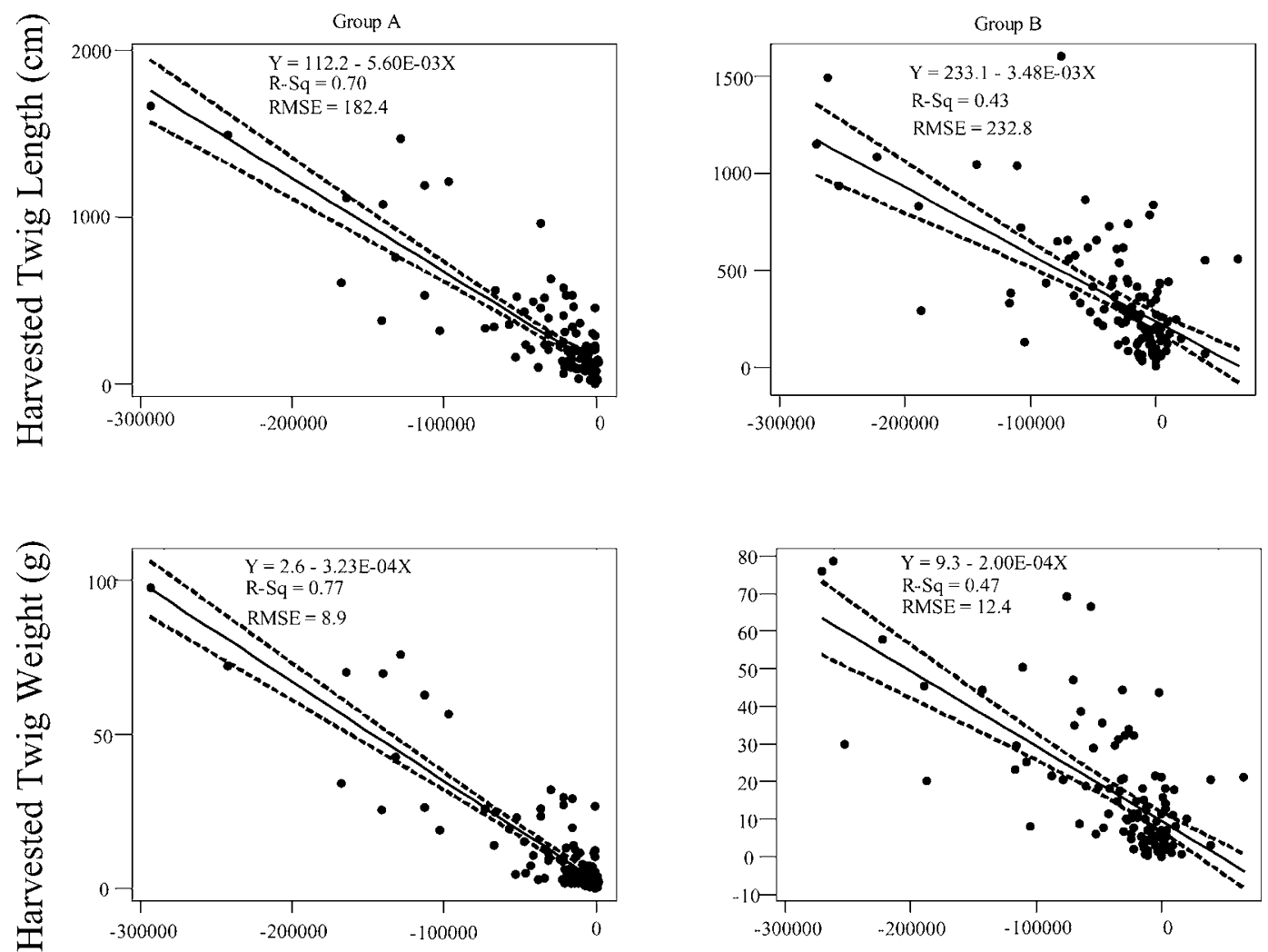

\section{Change in Canopy Volume $\left(\mathrm{cm}^{3}\right)$}

Figure 3. Simple linear regression functions (solid line) with 95\% confidence intervals (dashed lines), between change in canopy volume (cm ${ }^{3}$ ) and harvested twig length $(\mathrm{cm})$ and harvested twig weights $(\mathrm{g})$ for groups A (previous clipping history) and B (no clipping history). RMSE, square root of the mean square error (standard deviation of regression function).

of biomass as a larger, more diffuse canopy. Comparisons among treatments of residual aboveground biomass and corresponding final canopy volume illustrate this point (Table 4). Notably, while residual aboveground weights remained relatively consistent among treatments and were not statistically different, corresponding final canopy volumes varied immensely in size and were significantly different.

Therefore, a more consistent relationship between canopy volume estimates and aboveground biomass would be expected in willow plants placed under a chronic herbivory regime as illustrated by group A. In contrast, as exhibited by group B, plants with no previous history of responding to single-event defoliations would display a less significant relationship. Because willows in their natural environment are commonly subjected to frequent browsing events (Wolff 1978; Kindschy 1985; Kindschy 1989; Chadde and Kay 1991; Meiman 1996), it is reasonable to assume that the relationship between final canopy volume and residual aboveground biomass reported here for group A may be similar to what occurs in many natural willow communities.

The usefulness of canopy volume estimates in predicting aboveground production is well documented for several shrub species including serviceberry (Amelanchier alnifolia Nutt) by Lyon (1968); aspen (Populus tremuloides Michx.), beaked hazel (Corylus cornuta Marsh.), and pussy willow (Salix discolor Muhl.) by Peek (1970); and big sagebrush (Artemisia tridentata Nutt.) by Uresk et al. (1977), Rittenhouse and Sneva (1977), and Creamer (1991). The significance of the relationships between final canopy volume and residual aboveground biomass described here suggest that canopy volume estimates can also be useful in predicting aboveground production in planeleaf willow communities.

While estimating available annual production is important in rangeland management, so is estimating the use of that annual production and subsequent short- and long-term effects. Thorne (1998) monitored wildlife and livestock herbivory in mountain willow communities and showed that canopy volume measurements taken over the course of a growing season can concurrently provide an index to use and an estimate of trend. In this study, we sought to further investigate the relationship between utilization-induced changes in canopy volume and willow twig production by regressing the seasonal changes in canopy volume on harvested twig length and weight. Repeatedmeasures ANOVA results indicated that change in canopy volume was not dependent on group $(P>0.10)$, nor was there a group $\times$ season interaction $(P>0.10)$. Harvested twig lengths and weights by season varied $(P<0.01)$ between groups $\mathrm{A}$ and $\mathrm{B}$ but lacked a group $\times$ season interaction $(P>0.10)$. Therefore, the regression functions between twig lengths and weights and change in canopy volume were developed for each group individually (Fig. 3). All regression functions between change in canopy volume and either 
harvested twig lengths or harvested twig weights were significant $(P<0.01)$ for groups A and B (Fig. 3).

Change in canopy volume explained more variability in harvested twig lengths and harvested twig weights in group A $\left(R^{2}=0.70\right.$ and 0.77 , respectively $)$ than in group $\mathrm{B}\left(R^{2}=0.43\right.$ and 0.47 , respectively). In both groups, harvested twig weight was related more to change in canopy volume than was harvested twig length (Fig. 3).

\section{MANAGEMENT IMPLICATIONS}

This study illustrates that the effect of clipping frequency on willow biomass production is not simply the result of an accumulation of clipping events. Planeleaf willow production was most affected by combinations of specific seasonal clipping events. Our results also suggest that the aboveground and belowground portions of willows are differentially affected by the frequency of browsing depending on whether they have experienced previous browsing events. Variable response patterns observed suggest that willows may respond to chronic browsing by allocating resources to shoot elongation in order to maintain photosynthetic rates proportionate with root demands. Conversely, willows with no previous history of browsing may initially respond to browsing by briefly modifying physiological function but may begin to alter resource allocation patterns in response to more frequent browsing.

These response patterns may be highly dynamic and sensitive to the frequency and spacing of browsing events. In the same way that the chronic herbivory response can be gained by increasing the frequency of browsing, it can be delayed or lost by spacing browsing events to allow for recovery. In addition, these differential response patterns may concurrently determine and be mediated by the amount of photosynthetic area remaining following browsing. Chronic browsing can produce plants that are small and dense with a high proportion of short shoots occupying intercanopy space. In contrast, willows with no history of browsing or responding to single events tend to be larger and more diffuse. Comparatively, willows with these 2 structurally different canopies may have similar amounts of aboveground biomass, but willows with small, dense canopies may have more photosynthetic area than those with large, diffuse canopies. While a browsing event may remove equal portions of the available biomass, willows with dense canopies likely retain more photosynthetic area than plants with diffuse canopies. Willows that retain more photosynthetic area following browsing may be better equipped to allocate resources to aboveground production and restore photosynthetic capacity to prebrowsing levels faster than plants that lose a greater part of their photosynthetic area. These results should, however, be verified in willow communities subjected to natural environmental variations and browsing.

The relationship between final canopy volume and residual aboveground biomass was sensitive to the structural differences between planeleaf willow plants with and without previous clipping histories. This may have been the result of differences in the relative proportion of short shoots to long shoots between the 2 groups. The significance in the regression functions for both groups of willows suggests that canopy volume can be used to predict aboveground biomass in planeleaf willows. We suggest that the use of canopy volume to concurrently estimate use and quantify trends in willow communities is possible. An index of use could be derived by converting the change in volume to a percentage or by using canopy volume estimates made over a specified time interval to estimate the change in available aboveground production.

\section{ACKNOWLEDGMENTS}

The authors wish to thank Carolyn Hull-Sieg and 2 anonymous reviewers who provided valuable comments on the manuscript.

\section{LITERATURE CITED}

Abernathy, S., AND I. D. Rutherford. 2001. The distribution and strength of riparian tree roots in relation to riverbank reinforcement. Hydrologic Processes 15: 63-79.

Bilbrough, C. J., AND J. H. RichaRds. 1993. Growth of sagebrush and bitterbrush following simulated winter browsing: mechanisms of tolerance. Ecology 74: 481-492.

Briske, D. D., AND J. H. Richards. 1995. Plants response to defoliation: a physiological, morphological and demographic evaluation. In: D. J. Bedunah and R. E. Sosebee [eds.]. Wildland plants: physiological ecology and developmental morphology. Denver, CO: Society for Range Management. p 635-710.

Caldwell, M. M., J. H. Richards, D. A. Johnson, R. S. Nowak, and R. S. Dzurec. 1981. Coping with herbivory: photosynthetic capacity and resource allocation in two semiarid Agropyron bunchgrasses. Oecologia 50:14-24.

Chadde, S. W., and C. E. Kay. 1991. Tall-willow communities on Yellowstone's northern range: a test of the "natural-regulation" paradigm. In: R. B. Keith and M. S. Boyce [eds.]. The Greater Yellowstone ecosystem: Redefining America's wilderness heritage. New Haven, CT: Yale University Press. p 231-262.

Chapin, F. S., III, and M. SLACK. 1979. Effect of defoliation upon root growth, phosphate absorption and respiration in nutrient-limited tundra graminoids. Oecologia 42:67-79.

Creamer, W. H., IV. 1991. Prediction of available forage production of big sagebrush [MS thesis]. Bozeman, MT: Montana State University.

DAHL, B. E. 1995. Developmental morphology of plants. In: D. J. Bedunah and R. S. Sosebee [eds.]. Wildland plants: Physiological ecology and developmental morphology. Denver, C0: Society for Range Management. p 22-58.

DeGrosbois, T., G. P. Kershaw, And J. R. EYTon. 1991. The regrowth production and allocation of Salix arbusculoides in three growing seasons following rightof-way clearing. Canadian Journal of Forestry Research 21:1171-1179.

Dowdy, S., and S. WeARDen. 1991. Statistics for research. 2nd ed. New York, NY: John Wiley \& Sons, Inc.

Dunaway, D., S. R. Swanson, J. Wendel, and W. Clary. 1994. The effect of herbaceous plant communities and soil textures on particle erosion of alluvial streambanks. Geomorphology 9:47-56.

EngeL, R. K. 1993. Root and shoot responses of sand bluestem to defoliation [PhD dissertation]. Laramie, WY: University of Wyoming.

Engel, R. K., J. T. Nichols, J. L. Dodd, and J. E. Brummer. 1998. Root and shoot response of sand bluestem to defoliation. Journal of Range Management $51: 42-45$.

Green, D. M., and J. B. Kauffman. 1995. Succession and livestock grazing in a northeastern Oregon riparian ecosystem. Journal of Range Management 48: 307-313.

Groeneveld, D. P., and T. E. Griepentrog. 1985. Interdependence of groundwater, riparian vegetation, and streambank stability: a case study. In: Proc. Symposium on Riparian Ecosystems and Their Management. USDA Forest Service General Technical RM12Q. Tucson, AZ: USDA. p 44-48.

Kauffman, J. B., and W. C. Krueger. 1984. Livestock impacts on riparian ecosystems and streamside management implications... a review. Journal of Range Management 37:430-438. 
KINDSCHY, R. R. 1985. Response of red willow to beaver use in southeastern Oregon. Journal of Wildlife Management 49:26-28.

KINDSCHY, R. R. 1989. Regrowth of willow following simulated beaver cutting. Wildlife Society Bulletin 17:290-294.

Kleinfelder, D., S. Swanson, G. Norris, and W. Clary. 1992. Unconfined compressive strength of some streambank soils with herbaceous roots. Soil Society of America Journal 56:1920-1925.

Lauenroth, W. K., and W. C. Whitman. 1971. A rapid method for washing roots. Journal of Range Management 24:308-309.

LyoN, L. J. 1968. Estimating twig production of serviceberry from crown volumes. Journal of Wildlife Management 32:115-119.

Meiman, P. J. 1996. Effects of large ungulate herbivory on willow (Salix) in mountain rangelands of northern Wyoming [MS thesis]. Laramie, WY University of Wyoming.

MYeRS, T. J., AND S. Swanson. 1992. Variation of stream stability with stream type and livestock bank damage in northern Nevada. Water Resources Bulletin 28:743-754

Neter, J., M. H. Kutner, C. J. Nachtsheim, and W. Wasserman. 1996. Applied linear regression models. 3rd ed. Chicago, IL: Richard D. Irwin, Inc.

PeEk, J. M. 1970. Relation of canopy area and volume to production of three woody species. Ecology 51:1098-1101.

PLATTS, W. S. 1981. Effects of sheep grazing on a riparian-stream environment. USDA Forest Service Research Note, INT-307. Ogden, UT: Intermountain Forest and Range Experiment Station.

RICHARDS, J. H., AND M. M. CaLdwell. 1985. Soluble carbohydrates, concurrent photosynthesis and efficiency in regrowth following defoliation: a field study with Agropyron species. Journal of Applied Ecology 22:907-920.

RitTenhouse, L. R., And F. A. SNeva. 1977. A technique for estimating big sagebrush production. Journal of Range Management 30:68-70.

Roath, L. R., and W. C. Krueger. 1982. Cattle grazing influence on a mountain riparian zone. Journal of Range Management 35:100-103.
Simon, A., And A. J. C. Coluison. 2002. Quantifying the mechanical and hydrologic effects of riparian vegetation on streambank stability. Earth Surface Processes and Landforms 27:527-546.

Singer, F. J., L. C. Mark and R. C. Cates. 1994. Ungulate herbivory of willows on Yellowstone's northern winter range. Journal of Range Management 47:435-443.

Skinner, Q. D., T. L. Reeves, J. R. Turner and V. Hasfurther. 1989. Simulated climate and shale pile response within a large scale environmental chamber developed in Wyoming. In: D. J. Lazar [ed.]. Proc. 1989 Eastern Oil Shale Symposium. Lexington, KY: Institute of Mining and Mining Research. p 386393.

ThoRne, M. S. 1998. Effects of large ungulate herbivory on willow (Salix) canopy volume on mountain rangelands of northern Wyoming [MS thesis]. Laramie, WY: University of Wyoming.

Thorne, M. S., Q. D. Skinner, M. A. Smith, J. D. Rodgers, W. A. Laycock, and S. A. CEREKCI. 2002. Evaluation of a technique for measuring canopy volume of shrubs. Journal of Range Management 55:235-241.

Uresk, D. W., R. O. Gilbert, and W. H. Rickard. 1977. Sampling big sagebrush for phytomass. Journal of Range Management 30:311-314.

Vonesh, E. F., AND V. M. Chinchilli. 1997. Linear and nonlinear models for the analysis of repeated measurements. New York, NY: Marcel Dekker, Inc.

Willard, E. E., and C. M. McKell. 1978. Response of shrubs to simulated browsing. Journal of Wildlife Management 42:514-519.

Wolfe, M. L., W. H. BABCOCK, AND R. M. WelCH. 1983. Effects of simulated moose browsing on Drummond's willow. Alces 64:14-35.

WolfF, J. 0. 1978. Burning and browsing effects on willow growth in interior Alaska. Journal of Wildlife Management 42:135-140.

Zonge, K. L., S. Swanson, AND T. Myers. 1996. Drought year changes in streambank profiles on incised streams in the Sierra Nevada Mountains. Geomorphology 15:47-56. 